\title{
Article \\ Croatian LADM Profile Extension for State-Owned Agricultural Land Management
}

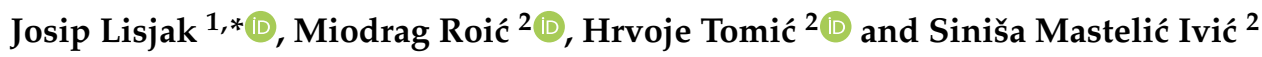 \\ 1 City of Požega, Trg Sv. Trojstva 1, HR-34 000 Požega, Croatia \\ 2 Faculty of Geodesy, University in Zagreb, Kačićeva 26, HR-10 000 Zagreb, Croatia; mroic@geof.hr (M.R.); \\ htomic@geof.hr (H.T.); ivic@geof.hr (S.M.I.) \\ * Correspondence: josip.lisjak@pozega.hr
}

check for updates

Citation: Lisjak, J.; Roić, M.; Tomić, H.; Mastelić Ivić, S. Croatian LADM Profile Extension for State-Owned Agricultural Land Management. Land 2021, 10, 222. https://doi.org/ 10.3390/land10020222

Received: 19 January 2021

Accepted: 18 February 2021

Published: 23 February 2021

Publisher's Note: MDPI stays neutral with regard to jurisdictional claims in published maps and institutional affiliations.

Copyright: (c) 2021 by the authors. Licensee MDPI, Basel, Switzerland. This article is an open access article distributed under the terms and conditions of the Creative Commons Attribution (CC BY) license (https:// creativecommons.org/licenses/by/ $4.0 /)$.
Abstract: The paper presents a conceptual model for the disposition of state agricultural land. The model is made as an extension of the Croatian Land Administration Domain Model (LADM) country profile. The LADM 19152:2012 is an International Organization for Standardization (ISO) standard which provides a formal language to describe the basic information-related components of land administration. The aim of this research is to assess the possibility of using the LADM extension to efficiently manage state-owned agricultural land. Since more than half of state-owned agricultural land in Croatia is not activated, the priority is to increase usage and activate uncultivated agricultural land by users through disposition process. The disposition process is highly regulated and complex in procedures, and it poses difficulties for organizations in the implementation of disposition, so a model of successful management is necessary. The disposition process and the necessary steps are shownmainly defined by legal regulations_and divided into two phases: the first phase is the development of the Program of Disposition of State-Owned Agricultural Land where the multi-criteria decision analysis (MCDA) for land potential analysis is crucial; the second phase is the realization of the disposition. In line with the disposition process, a Unified Modeling Language (UML) model for this LADM extension on the conceptual level was developed and is presented herein. Finally, the improvement of the agricultural land management system and the related processes are reviewed.

Keywords: agricultural land management; land disposition; Croatian country profile extension; LADM; state-owned agricultural land

\section{Introduction}

Recently, in Croatian governmental and law-making bodies, there have been calls for change in agricultural land management. This is particularly true for state-owned agricultural land because there are many cadastral parcels of agricultural land that remain unused. To illustrate the significance of the issue and the subject of this paper, it is important to elaborate on the land typology in Croatia and certain ownership divisions. According to [1], out of a total area of approximately 8.8 million ha, 4.3 million hectares have the common good status, 3.0 million ha are state-owned, 0.013 million ha are owned by the regional/local self-government units, and 2.6 million ha are privately owned. Out of this 8.8 million ha, 2.7 million ha are agricultural land. Therefore, more than $30 \%$ of the total area of the Republic of Croatia is agricultural land. The Republic of Croatia owns 33\% of the overall agricultural land, while the share of state-owned land in the total area of 8.8 million is more than $34 \%$.

According to the main directives regarding development in agriculture in Croatia [2], it is considered to be a priority to increase usage and activate uncultivated agricultural land, i.e., increase agricultural production. Uncultivated land is non-overgrown forest land and land overgrown with initial or degradation development land stages of forest stands (maquis, garig, shrubs, etc.) and is suitable for agricultural production. Uncultivated land 
is agricultural land which is not prepared for raising crops or is not used in any other agricultural way, so it is not put to economic function.

Since the 1991 Law on Agricultural Land [3], by which all agricultural land that was socially owned became property of the state, the state has been trying to find ways in which to put the agricultural land at its disposition into economic functioning. However, the results have not been successful and large areas of agricultural land remain uncultivated and neglected, including both state-owned land and land owned by natural and legal persons. Fragmentation of holdings and the need to aggregate agricultural land for agricultural production should be a priority in future development of agriculture in Croatia [4]. Since 1991, the Law on Agricultural Land has been amended several times because there were significant weaknesses in its implementation that impeded the disposal of farmland [5]. Complementary to this, in [6], the authors conclude that fragmentation of holdings is one of the limitations for achieving sustainability of agricultural holdings. Therefore, state-owned agricultural land should be put to use and cultivated. The way to realize this is through state-owned agricultural land disposition. There are defined forms of disposition, such as sale, lease, re-expropriation, lease for fishponds, lease for common pastures, and other uses.

As can be seen in surrounding countries, the countries of Central and Eastern Europe (CEE) went through a similar transition process from planned to market economy, in order to create a new agricultural structure based on private ownership and a marketoriented economy. Most CEE countries opted to sell state-owned agricultural land and return the cooperative agricultural land to its rightful owners, thus enabling farmers to expand their production capacity and strengthen their businesses. According to research on state-owned agricultural land disposition in Croatia in comparison with countries of CEE [5], the issues in this process are similar in the majority of CEE countries. Until the geodetic survey is performed and land property and legal issues are resolved (which is a long-term and expensive process), the land set for sales has been temporarily leased. In the Czech Republic, 25\% of the state-owned agricultural land was disposed that way, in Slovakia 15\%, in Poland 19\%, and Eastern Germany 7\%. Findings from this research also showed that although the special Agency for Agricultural Land has been established, it has no influence, and this is the case with other countries of the CEE, where "land funds" have been formally established, or the so-called state land reserves for the purpose of land consolidation (Slovenia, the Check Republic, Slovakia, Poland) [5].

Therefore, the forms of disposition are similar in surrounding countries as they are in Croatia, as well as the issues that arise in the process.

Regarding the performance of disposition in the Republic of Croatia, from the Final report on Implementation of the Land Governance Assessment Framework (LGAF) in the Republic of Croatia [1], until 2013, 552,503 ha of state-owned agricultural land was available for disposition. Out of that, disposition contracts were concluded for approximately $48 \%$ $(263,307 \mathrm{ha})$, while approximately $52 \%(289,196 \mathrm{ha})$ of the state-owned agricultural land remains unused.

However, in [5], slightly different statistic data on agricultural land is presented. According to this research, there are 890,214 ha of state-owned agricultural land in Croatia, and according to local self-government programs, approximately $61 \%$ of state-owned agricultural land is available for disposition. This research concluded that Croatia has not managed to accomplish the goals set by local self-government programs and only around $21 \%$ of the state-owned agricultural land has been offered for disposition by public tenders (sales, lease, concession, re-expropriation, and other purposes), while more than 700,000 ha are still available.

This low proportion of state-owned agricultural land activation, and the differences in statistical data on agricultural land use, implies that there are difficulties in land management and the interpretation of different registers, which justifies the need for an efficient agricultural land management model based on interoperability and relation between existing registers. 
Through recent history, the authority for state-owned agricultural land has switched from ministries to local authorities, and at some stage, a special agency for state-owned agricultural land was founded. With these frequent organizational and formal changes, agricultural land has not been efficiently activated. The initiative for agricultural land reactivation started with law regulations and the transfer of authority back to local administration; however, the overall process of agricultural land management should utilize the novel technologies available today. In 2015, the Information System for State-Owned Agricultural Land (ISAPZ) was introduced. The increase in the available area, and thus the increase in revenues to the state budget from state-owned agricultural land management, is directly related to the development and use of ISAPZ [7].

Agricultural land management requires an interdisciplinary approach and depends on various parameters (i.e., datasets) from different fields managed by different institutions. Multi-criteria decision analysis (MCDA) should be performed, and location potential should be determined, for procedures which comprise different spatial datasets from across spatial themes range and disciplines, in order to effectively program the disposition plan. Therefore, a general comprehensive model for land management should be applied to manage agricultural land.

Existing models that address land management, as well as agricultural land management, include the Land Administration Domain Model (LADM) [8], then, regarding the implementing rules of the Infrastructure for Spatial Information in the European Community (INSPIRE) directive, there is data specification on cadastral parcels [9], for land cover [10], and specifically for the agricultural land there is the Land Parcel Identification System (LPIS). While LPIS is already implemented in Croatia by the Paying Agency for Agriculture, Fisheries, and Rural Development in the Republic of Croatia (known as ARKOD), the Land Administration Domain Model has been recognized as optimal for the purpose of state-owned agricultural land disposition and has been in place since 2012 as the ISO standard [8]. Through its recognition as an ISO standard, the significance of LADM from an international perspective is confirmed. Furthermore, its growing influence is revealed by the multiple country profiles that have been developed so far in various jurisdictions across the world, which are elaborated in [11]. According to this research, there are 23 country profiles developed for territorial jurisdiction of countries across the world whilst every continent (except North America) is represented by at least one country profile. Thus far, the country profiles have been developed for jurisdictions of Colombia, Cyprus, Czech Republic, Greece, Hungary, Indonesia, Israel, Japan, Korea, Malaysia, Montenegro, Poland, Portugal, Queensland, Republic of Srpska, Russian Federation, Serbia, South Africa, The Netherlands, Trinidad and Tobago, Turkey, Victoria, and finally, Croatia [11].

The model proposed in this paper presents an intermediate step between the LADM and LPIS regarding state-owned agricultural land management. The cadastral parcel before it is cultivated and before it is activated should be observed as a whole parcel and by which is a subject of LADM, while only after it is disposed can be put to use as reference agricultural parcel in LPIS.

The main concepts and rules that LADM comprises can be applied to agricultural land management, and some adaptations in the form of extensions could be applied to state-owned agricultural land management in Croatia.

Although the incentive for this research was the current problem of state-owned agricultural land disposition, the extension of the model seeks to adapt its applicability to agricultural land management overall, and thus agricultural land administration. The measurements of land management are realized through the use of the previously mentioned land administration systems. In terms of the stratification of land domain levels or hierarchy which are clearly presented in [12], such a model should ultimately be suitable and have an impact in the broadest terms, i.e., Land Policy. The focus of this research and extension proposal was the disposition of state-owned cadastral parcels of agricultural land, preferably within a comprehensive land administration system. As a result, a general 
model (LADM) that is applicable in the entire domain of land administration was used both as the basis and the means of guiding the adjustment within it.

\section{Land Administration Domain Model (LADM)}

Land administration is a large field; the focus of the LADM is the part of land administration that is interested in rights, responsibilities, and restrictions affecting land and the corresponding geometrical (geospatial) components. The LADM is a conceptual model, and not a data product specification. The LADM is a descriptive standard, not a prescriptive standard. The International Standard, published as ISO 19152, covers the basic information related to components of land administration (including water and elements above and below the earth's surface). This standard is currently under revision, and the International Federation of Surveyors (FIG) submitted a New Working Item Proposal

(NWIP) to ISO on the development of the LADM Edition II in April 2018 [13], which has still not been approved. This New Working Item Proposal includes scheduled LADM extensions regarding the extended scope of the conceptual model, the improvement of the model, encodings/technical models towards LADM implementation-such as CityGML, GeoJSON, etc.- - and process models for survey procedures, map updating, and transactions, including blockchain technology.

The approved official version of the LADM [8] includes agreements on data concerning administrative and spatial units, land rights in a broad sense, and source documents (e.g., deeds or surveys) [14]. The LADM could be called, in the INSPIRE sense, a "generic conceptual model", which is intended to be adapted to any local or regional environment in the land administration domain.

The LADM is an object model described by classes. The LADM core consists of four basic classes that describe the relations between persons and the objects of registration. Those classes are LA_Party (Person), LA_BAUnit (Basic administrative unit), and LA_RRR (Right, Restriction, and Responsibility). The objects of registration are spatial units determined by their spatial position (LA_SpatialUnit) (Figure 1).

However, the following is outside of the scope of this International Standard: interference with (national) land administration laws that may have any legal implications; construction of external databases with party data, address data, valuation data, land use data, land cover data, physical utility network data, archive data, and taxation data. The LADM provides stereotype classes for these datasets to indicate which dataset elements the LADM expects from these external sources, if available, and the modeling of land administration processes [8].

\subsection{LADM Packages}

The LADM consists of three main packages: Party, Administrative, and Spatial Unit package. LADM is described in detail in [8,14-16]. Each package consists of the classes within and relations between them.

The Party package consists of the LA_Party class as the generalization class with its specialization LA_GroupParty. Parties can be a natural person or a legal entity such as an organization that has certain rights over the spatial unit.

Therefore, it is related to the Administrative package, i.e., the LA_RRR generic class. This generic class within the Administrative package has its specializations: LA_Right, LA_Restriction, and LA_Responsibility. Within the package, there is also the LA_BAUnit class. This class represents the basic administrative unit, which can contain one or more different spatial units.

Spatial units package elaborates spatial units. This package consists of the following classes: LA_SpatialUnit as the "core" class, then LA_SpatialUnitGroup, LA_Level, LA_LegalSpaceBuildingUnit, LA_LegalSpaceUtilityNetwork, and LA_RequiredRelationship SpatialUnit. 
The LA_SpatialUnit class has two specializations. The first is LA_LegalSpace BuildingUnit and is designed for buildings, while the other specialization is LA_LegalSpace UtilityNetwork, which is designed for utilities.

The LA_RequiredRelationshipSpatialUnit class is designed for cases when geometry data from the spatial units are not sufficiently accurate to provide reliable results while running the computer spatial operations (for example, a building that is, in reality, completely within the boundaries of a certain cadastral parcel, but due to inaccurate spatial data, partially falls outside of it). In that case, the accurate connections between certain spatial units are determined with the help of the mentioned class [17].

The Spatial Unit package also has one Surveying and Representation Sub-package with classes such as LA_SpatialSource, LA Point, LA_BoundaryFaceString, and LA_ BoundaryFace [16]. This package can be used to describe origin, measurements, methods, and ways of data production for spatial units.

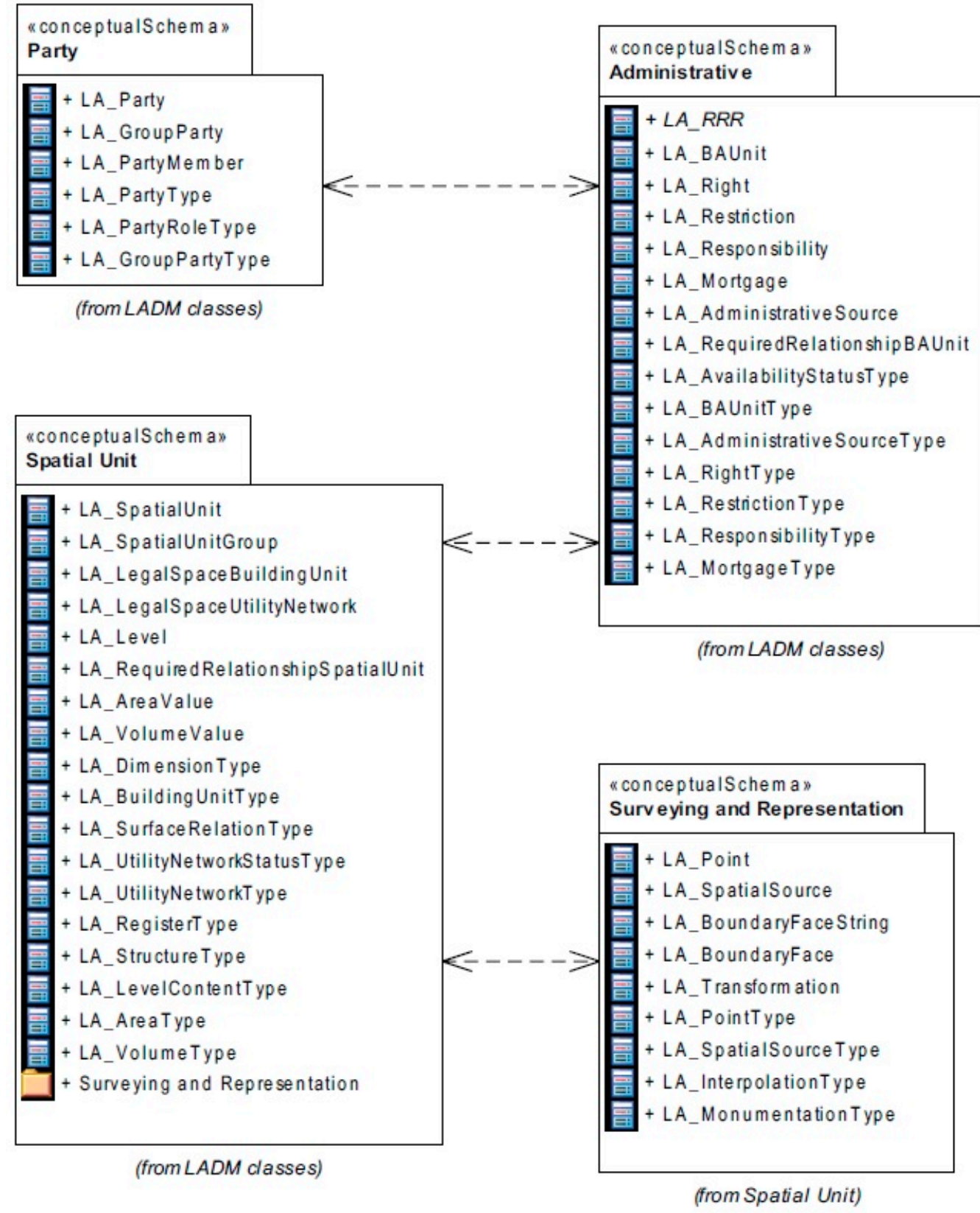

Figure 1. The LADM overview of (sub)packages (with their respective classes) (ISO 19152). 
On top of these packages and the classes within, it is expected to extend or adopt the model for land administration to local situations and needs. Following that, the proposal for a Croatian Country profile was introduced for the first time in 2013 in [18].

\subsection{Croatian Country Profile LADM}

As previously mentioned, the first version of the Croatian LADM profile was created in 2013. Later, some additional changes to the proposal were made regarding the prefix of the proposed new classes (the CRO prefix was changed to HR), some new attributes in the code lists were introduced, and some new classes were added to certain packages in [19], while UML model is displayed in Figure 2. Afterwards, the LADM fiscal/valuation extension of the Croatian Country profile was proposed in [20], where a similar schema matching process to that described herein was conducted.

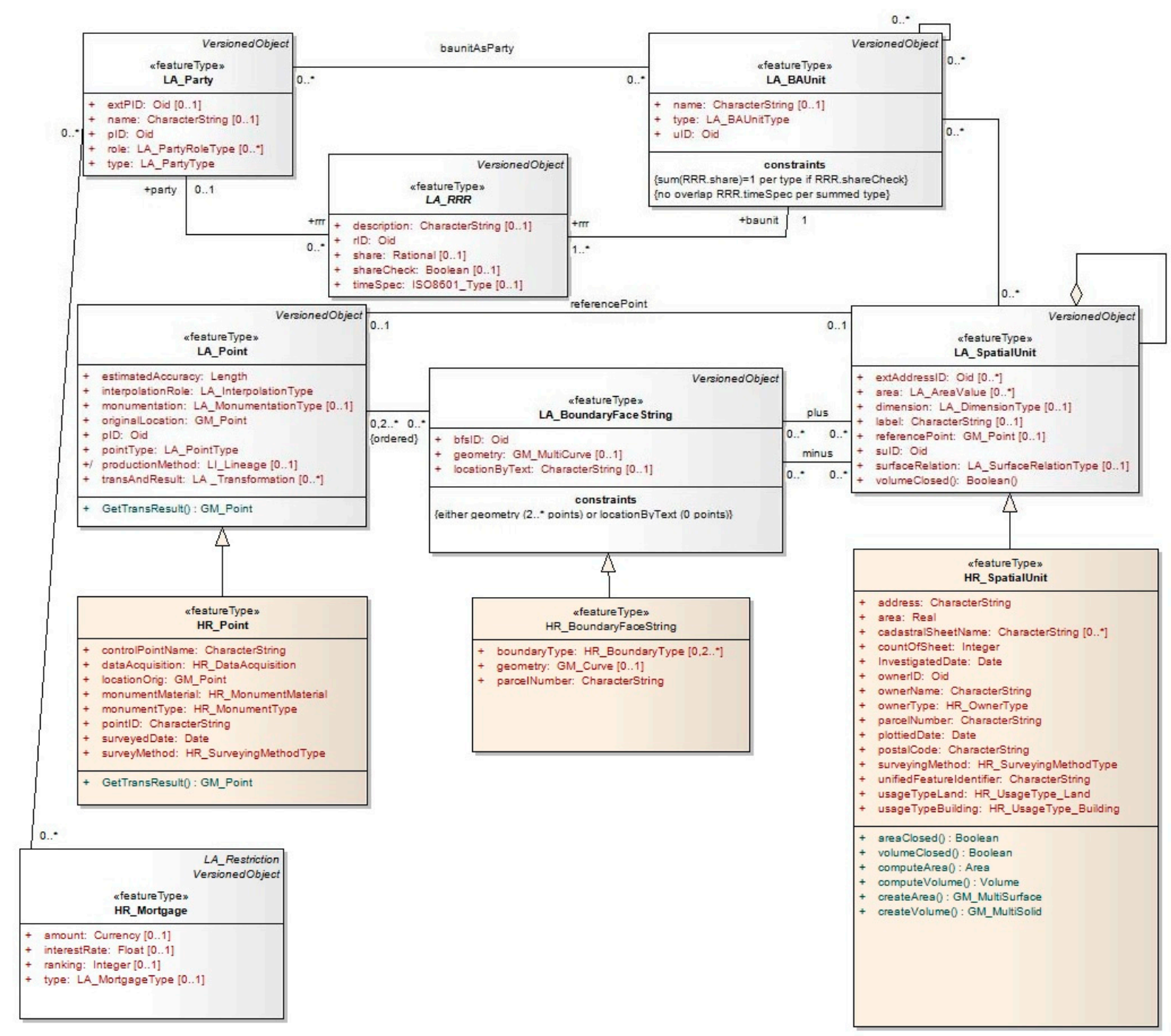

Figure 2. Croatian country profile LADM diagram [19].

The class LA_Party—with its specialization LA_GroupParty — can be applied directly to the Croatian Land Administration System (LAS). The types in the code lists were changed and added to suit the Croatian LAS. The attributes and relations in the administrative package of the Croatian Country profile are similar to the LADM, and all classes of the Administrative package can be applied directly to the Croatian Land Administration System. The types in the code lists were changed and added to suit to the Croatian LAS. The spatial unit package presents the spatial attributes of the cadastral parcels, buildings, 
and other immovables associated with land. The surveying and representation subpackage shows the data related to technical features concerning land use. All classes of the surveying and representation package can be applied directly to the Croatian Land Administration System [19].

Therefore, the Croatian Country profile is proposed with only a few elements of adaptation of the generic LADM to the local situation. This implies that the Croatian Land Administration System can indeed implement the LADM. An argument to confirm this is the recent efforts in law regulation changes. The novelty in the new Law on Communal Economy [21] is that the real property, or cadastral parcel (read: SpatialUnit), can be charged for communal tax in cases when currently there are no owners or users. This is in conformance with the logic in the LADM, where a "basic administrative unit" may play the role of a "party" because it may hold a right of easement over another, usually neighboring, spatial unit. Besides this, it may hold a responsibility, or restriction, because of a mortgage [14]. This was also the case in land book practice before, but now, with the special law that regulates communal tax, this has been adopted to enable the SpatialUnit to play the role of a "party", as it can be charged for communal tax.

\section{Methodology}

The methodology used in this research is mostly in line with the suggested methodological steps to develop LADM country profiles which are proposed in [11]. For the analysis of the requirements defined in the national legislative framework and other relevant regulations regarding subject domain, agricultural land disposition is performed as the first step, the scope of the existing country profile is analyzed and defined, and with respect to that our profile extension is defined as future proof (it should include new elements/classes that are not currently registered at all, or are not registered by the mapping authority), the extension modelling is performed on the conceptual level, and is performed in the Unified Modeming Language (UML) using tools that support the Model Driven Architecture (MDA)-based approach, concretely the Enterprise Architect (EA). The methodology behind this research followed the specifically emphasized activities in [11], and they include the following:

- inheritance from LADM core classes the relevant country-specific classes using a prefix denoting the country (eg. "HR" for Croatia);

- creation of new classes to serve the needs of the country, only when the existing concepts do not fit to the existing LADM classes (done through the schema matching process);

- $\quad$ addition of new attributes, if needed, to address the national needs and requirements;

- maintaining associations as defined in LADM;

- $\quad$ adjusting cardinalities according to national regulations and/or define relevant constraints to be imposed;

- the addition of new values to existing code lists. The hierarchical structure of code lists as presented in Annex J of the of ISO_WD1_19152_TC211 are used (new code lists were proposed only for newly proposed attributes, but not for the existing attributes)

- $\quad$ usage of the external classes to link the model with current external registries.

The inputs used in this research are the laws regulating the agricultural land domain and the publicly available official forms that accompany the regulations. The objective was to identify a source land management schema (the existing Croatia country profile elaborated in Section 2.2) and a target land management schema appropriate for stateowned agricultural land management (the input is shown in detail in Section 4.1, Table 1). For the target scheme, a data model was developed for the management of state-owned agricultural land with all the attributes and relationships provided by the legislation. In the research, we used methods of analysis from existing formal land management models, through which we identified that there was a specific localized LADM model (Croatian country profile LADM) suitable for the analysis and extension. A schema matching procedure comparing the existing model and the target model was performed. Schema matching 
is a fundamental operation in the manipulation of schema information, which takes two schemas as inputs and produces a mapping between the elements of the two schemas that correspond semantically [22]. This is the first step in semantic mapping between a source schema and a target schema, and it is used to create a set of correspondences between schema elements [23]. As a result of the relatively low number of elements to match, it was possible to conduct the schema matching process manually.

After we matched the corresponding elements in the source schema (Croatian country profile LADM), we modeled the extension of this schema, to be applicable to the conditions and requirements of the law regulative and stipulated processes, with all the elements that were not recognized in the source schema.

To create a model extension diagram, we used the Unified Modeling Language (UML), which can be defined as a general-purpose visual modeling language for specifying, visualizing, constructing, and documenting artifacts in a software system [24]. It is appropriate for visualizing cadastral systems as a core component of land administration systems. The existing land administration system in Croatia was analyzed and various shortcomings were highlighted. With respect to these shortcomings and the proposed model extension, suggestions for improvements are elaborated herein.

\section{Croatian Country Profile LADM for a State-Owned Agricultural Land Management Proposal}

Since 2018, the disposition of cadastral parcels of agricultural land owned by the Republic of Croatia has been returned to the jurisdiction of the local self-government units in whose territory the land is located. The new Law on Agricultural Land [25] stipulates that local self-government units should develop a Program of Disposition of State-Owned Agricultural Land (referred to as Program) on the basis of which they will dispose such cadastral parcels in the future and publish a call for tenders [26]. The procedure for this is also defined with a bylaw [27]. This bylaw stipulates that the obligatory data should be obtained through traditional data exchange methods, i.e., by e-mail and by written reports from certain public institutions. These data therefore represent static data valid on a certain date. Examples of reports (obligatory data) defined in the bylaw are as follows: a written statement from the company for forest management, Croatian Forests Ltd., whether some of the cadastral parcels are within the forest management basis; a written statement from the authority in charge for water management in Croatia, Croatian Waters, whether some of the cadastral parcels represent public water area; a written statement and the attached list of cadastral parcels within the construction area from the body in charge of urbanism; etc. It can already be seen that there are various potential public rights and restrictions issues regarding this.

Some of the public rights and restrictions cover a significant area of the Republic of Croatia. Water areas represent 7.0 million ha, agricultural land 2.7 million ha, protected areas 0.7 million ha, protected coastal areas 0.8 million ha, forests and forest lands 2.7 million ha, hunting grounds 2.2 million ha, fishing zones 5.5 million ha, and cultural assets 0.001 million ha [1]. From this, it can be concluded that many legal regimes overlap, which can sometimes cause difficulties in determining competencies for management or authority over certain land parcels [28].

Therefore, this type of prescribed method of data exchange for the purposes of drafting the Program makes it difficult to determine the status of individual cadastral parcels efficiently and accurately. The process of drafting the Program is essentially the procedure of evaluating and categorizing cadastral parcels, i.e., determining the potential of land for a particular means of disposition. Accordingly, it is necessary to implement a multi-criteria decision analysis (MCDA) and to use and combine different data sources from different data themes.

The process of disposition of state-owned agricultural land, as it is defined with current regulations, is described in the activity diagram in Figure 3. 


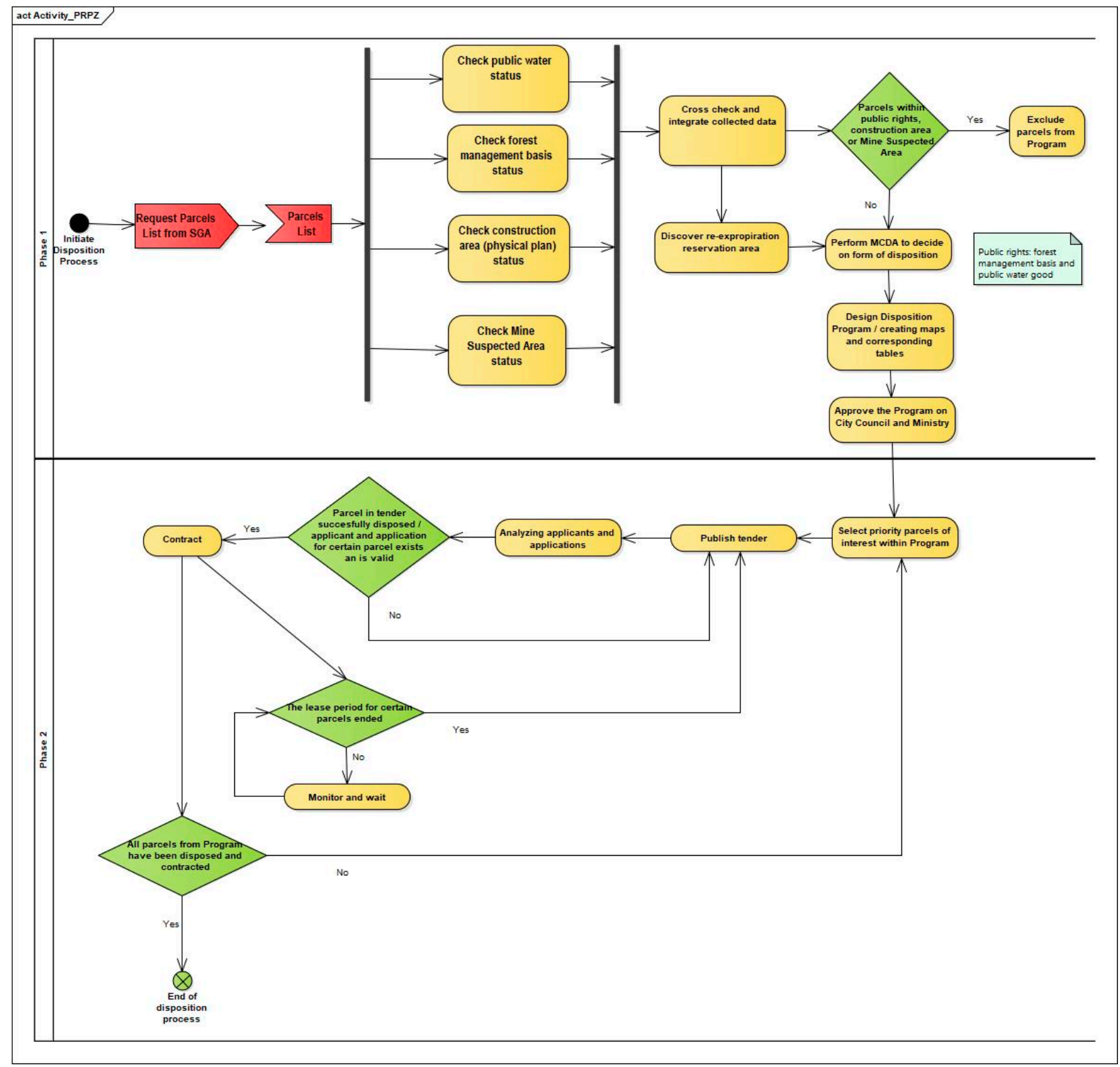

Figure 3. Activity diagram of the of state-owned agricultural land disposition process.

The disposition process starts with the City Council decision on initiating Program development. The first step after the City Council decision is request the State Geodetic Administration to provide a list of cadastral parcels owned by the state, which have agricultural usage. Once the list is acquired, the local administration in charge of the design of the Program sends a request with the attached list of cadastral parcels to Croatian Waters to acquire information as to whether any cadastral parcels from the list are under the public water area public right. At the same time, the request with attached cadastral parcels list is sent to Croatian Forests, and to the department in charge for urbanism, as well as to the Croatian Mine Action Center to acquire information as to whether any cadastral parcels (and which specific ones) are within the forest management basis, a construction area, or within a Mine Suspected Area. These statements are usually delivered in analogue form, mostly with an attached .xls table. Once the statements are delivered, it is necessary to integrate the data from these statements, and to insert the data into a single list of cadastral parcels. According to the regulations, the parcels which meet at least one of the conditions (are within public water area, forest management basis, Mine Suspected Area, or a construction area) cannot be part of the Program, i.e., they should be excluded from 
the process of Program design. In parallel, the information on the overall area that should be reserved by the Program for re-expropriation of nationalized land should be acquired in a statement from the authority that resolves re-expropriation and denationalization issues. This area needs to be considered when designing a disposition Program, and some of the cadastral parcels with a sum area of at least this size should be designated for this form of disposition-re-expropriation. In addition, the multi-criteria decision analysis is performed to decide which of the cadastral parcels are left on the list, and those suitable for disposition should be designated to which form of disposition. This step can include a range of several hundreds of cadastral parcels to several thousands of cadastral parcels. The legal criteria are listed in Section 4.1, and the qualitative criteria for sorting of parcels by form of disposition are described in [26].

After the MCDA process and the sorting of the cadastral parcels by assigning attributes for the form of disposition, corresponding maps with parcels marked based on the form of disposition and attribute tables are created. This is the finalization of the Program, which needs to be approved by the City Council and Ministry of Agriculture.

Once the Program has been approved, the second phase of the state-owned agricultural land disposition process can begin. Depending on the interest in certain cadastral parcels from a valid Program and the City policy, a certain number of cadastral parcels (or in rare cases, all parcels) is selected from the Program. A tender is then created for these cadastral parcels, which is published in order to dispose them in the way defined in the Program. After that, applications are received, which are analyzed by a special commission in order to assess whether they meet the conditions of the tender. Applications are evaluated and ranked, and a final decision on the assignment of each cadastral parcel is made. For successful applications and cadastral parcels, a contract is signed. If for certain cadastral parcels, there are no applications or there are no valid applications, then the tender can be repeated. If there are cadastral parcels within the Program for which the disposition tender is not published, then the entire process starting from phase two can be repeated. The tendering repeats until there are no cadastral parcels left in the Program for disposition, which is the final goal. This can only be realized in theory, as in practice, it is unlikely that every single state-owned cadastral parcel will be disposed successfully. After the realization of the lease contract, the disposed cadastral parcels are continuously monitored, in order to publish tender for those cadastral parcels for which the lease period has expired.

In general, the process of state-owned agricultural land management can be divided into two phases: phase one, the preparation and development of the Program; and phase two, the implementation of the program, i.e., disposition.

\subsection{Creating a Program of Disposition of State-Owned Agricultural Land}

When developing the Program, it is necessary to consider several factors and constraints that are mainly stipulated by the current Law on Agricultural Land [25]. In addition to the stated methods of data exchange and the mandatory data and documentation that need to be collected for the preparation of the Program, the final result, i.e., the appearance of the Program, is defined. The Ministry of Agriculture introduced and published the table form (Table 1) for cadastral parcels of agricultural land within the Program, with certain attribute data for the entities.

For attributes under $1-7$, corresponding data were recognized in the LADM in the schema matching process, e.g., we identified the Cadastral municipality name and Cadastral municipality ID attributes as name and sugID attributes in HR_SpatialUnitGroup class in Croatian country profile LADM, then Parcel number and Parcel area as parcelNumber and area in HR_SpatialUnit class in Croatian country profile LADM, etc. Attributes under 8-12 were not matched to any class attribute in LADM, and they need to be modeled in the proposed extension. 
Table 1. The table form published by the Ministry of Agriculture which defines the necessary cadastral parcel attributes.

\begin{tabular}{cc}
\hline Attribute Nr. & Obligatory Attribute \\
\hline 1 & County \\
\hline 2 & Local self-government unit \\
\hline 3 & Cadastral municipality name \\
\hline 4 & Cadastral municipality ID \\
\hline 5 & Parcel number \\
\hline 6 & Parcel area (m $\left.{ }^{2}\right)$ \\
\hline 7 & Cadastral usage type \\
\hline 8 & Planned form of disposition \\
\hline 9 & Specifics from LandUse plan \\
\hline 10 & Previous form of disposition \\
\hline 11 & Duration of disposition (until date) \\
\hline 12 & Note \\
\hline
\end{tabular}

The bylaw prescribing the documentation for the preparation of the Program explicitly defines: On the copy of the cadastral plan, it is necessary to mark the agricultural areas according to the form of disposition [27].

This implies that when creating the Program, it is necessary to graphically display the data and their geometry in a certain style. Therefore, it is necessary to use GIS techniques for the development and visualization, and the MCDA should be used as the basis for the land potential analysis and the layout of the disposition method. In accordance with the law, the criteria within the MCDA should be considered. Criteria can be set along two basic pillars: legal criteria and operational or qualitative criteria. The legal criteria, already partially described in the activity diagram and Section 4, are as follows:

- the cadastral parcel must not be within a construction area;

- the cadastral parcel must not be within the forest management basis;

- the cadastral parcel must not represent a public water area;

- area must not exceed 100 ha (for production-technological units);

- $\quad$ agricultural land marked as P1 or P2 quality (the labels for quality of arable land in physical plans, while P1 stands for very valuable arable land, and P2 stands for valuable arable land) according to the physical plan cannot be designated for sale by the Program (except for parcels of less than 1 ha in the continental area);

- agricultural cadastral parcels neighboring the construction area cannot be determined for sale by the Program [26].

Legal criteria must be met, and as such should be implemented in the extension of the LADM for the needs of agricultural land management. Qualitative criteria can be determined depending on local situations and decisions.

\subsection{Extension of the Croatian Country Profile LADM}

To formalize the management of state-owned agricultural land, a model based on the LADM is proposed. For this purpose, the processes and conditions assumed by the legislation in this domain were analyzed. After that, an attribute-based schema matching process against the Croatian LADM profile for existing and necessary attributes was conducted. The attributes required for the disposition of cadastral parcels of agricultural land, which are not contained in the basic LADM nor in the Croatian Country profile LADM, were identified based on the schema matching process.

The law is the framework that defines that a Program should be prepared, which must meet the conditions specified in Section 4.1. The fulfillment of these preconditions is shown 
in this proposed LADM extension through the constraints and class relationships. The interoperability of the system was considered, and the proposed model extension does not contribute to data redundancy.

The existence of redundant data in the public registers often leads to situations where information about a feature registered in a register does not match the information about the same feature in another register. Such a situation is the cause of a variety of unwanted consequences, which are burdensome for the relevant public authorities, but also for citizens, private companies, and other end users of that data. In an effort to address the current situation and move forward, the idea to use the LADM as a core that primarily covers land registers but can also be extended to the needs of the whole national system of registers emerged. It was expected that the logic and valuable ideas implemented into the LADM could be applied to other fields outside the scope of the LADM. To achieve this task, an overall analysis of all the official registers needed to be performed [29]. Along with this recommendation, the proposed extension was designed. To fulfill the conditions through relations between classes, the proposed extension uses a connection with external registers as much as possible. Thus, for location conditions, the relation to external registers, i.e., physical plans, is shown, instead of just adding attributes to existing classes. Therefore, in this extension, the new feature class HR_ALDP_parcel was proposed. The prefix HR stands for Croatian profile extension, and the abbreviation ALDP is from "Agriculture Land Disposition Program". This class contains the required attributes and is related to other classes in the LADM as required in the presented process. The same principle was used for modeling for the implementation phase of the program, i.e., land disposition (which includes tendering, administration of tenderers and contracts, other parties, etc.), where new the HR_PartyApplicant class was proposed as the specialization of the existing LA_Party class, and the Farmer class from the external Farmers register. The newly proposed classes and enumerations are shown in UML in Figure 4.

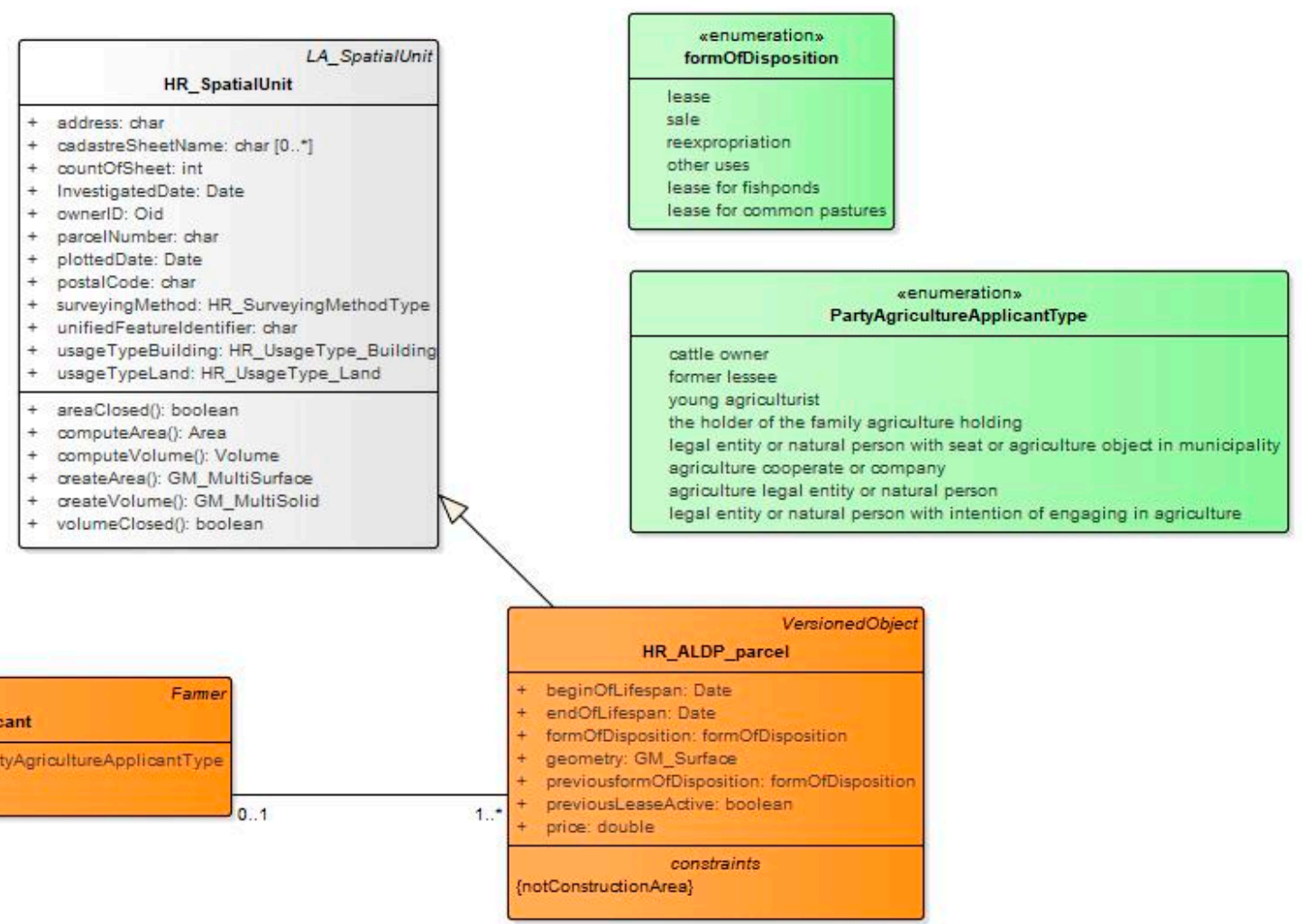

Figure 4. Newly proposed classes and enumerations. 
Fulfillment of the prescribed attributes in Table 1 was envisaged by proposing a new feature class, HR_ALDP_parcel, with defined appropriate attributes, but only those which the schema matching process determined do not inherit from their generic feature class, HR_SpatialUnit (attributes numbered 8-12 in Table 1). In accordance with the identified possible values for individual attributes that legal regulations leave as a possibility, the appropriate code lists and enumerations were created. The PartyAgricultureApplicantType enumeration was created with values defined in Law on Agricultural Land [25], which defines the type of applicant with a priority right when applying to tender. The FormOfDisposition enumeration was created as the most important one, because the possible forms of disposition are strictly defined by the Law. The HR_ALDP_parcel specialization class is related to the HR_PartyApplicant class. Thereby, for one or more agricultural cadastral parcels, there can be zero or one applicant (HR_PartyApplicant). This describes the possibility from Section 4, in which there are no applicants for certain cadastral parcels from the tender, but also one applicant can apply for more than one cadastral parcel from the tender. The HR_PartyApplicant class contains one attribute, PartyAgricultureApplicantType, which is defined in the previously described enumeration. Other important attributes, e.g., name, address, ID, can be inherited from the generic classes LA_Party and Farmer. Although, in the LA_Party class there is the attribute LA_PartyType, this is not the type of party in the sense of regulations for state-owned agricultural land disposition. They are very specific and determine that applicants can be cattle owners; former lessees; young agriculturists; legal entities or natural persons with a seat or agriculture object in the municipality; legal entities or natural persons with the intention of engaging in agriculture; the holders of the family agriculture holding; agriculture legal entities or natural persons; or agriculture cooperative or company.

The conditions for the cadastral parcel included in the Program, i.e., HR_ALDP_parcel, are modeled through relations with existing classes from the LADM, and from external systems. The precondition that the cadastral parcel cannot be under special public restrictions, such as forest management basis or public water area, are shown in relation with constraints, while these public restrictions are modeled as a specialization class of the generic class LA_Restriction. This specialization as a public restriction can be a public general restriction, and a public specific restriction. The values for HR_PublicSpecificRestrictionType are proposed in a code list. The forestManagementBasis, publicWaterArea, and mineSuspectedArea, which need to be addressed in the extension proposal, are recognized as public specific restrictions, since they are restrictions on particular individual properties, and can be represented at an instance level, not as an abstract class. This is modeled in line with the proposal for the extension of RRR described in previous research on further modeling of LADM rights, restrictions, and responsibilities [30].

The construction area constraint is modeled in relation with Land Use data, which exist in National Spatial Data Infrastructure (NSDI) or the geoinformation infrastructure as external systems. Since in Croatia, physical plans divide land use into construction area, forest area, and agricultural area, this constraint is modeled on the way that HR_ALDP_parcel can be within the composition of an agriculture area in LandUse, or within the composition of a forest area in LandUse. It cannot be in the composition of a construction area in LandUse.

The form of disposition is emphasized as the basic key attribute and backbone of the disposition of agricultural land process.

Furthermore, agricultural land disposition and the regulations related to the implementation of tenders primarily regulate the types of tenderers and the rights of priority. The model envisages a connection with an external register that keeps data on farmers. The feature class HR_PartyApplicant is proposed as a class specialization from the register of farmers, which is managed by the Paying Agency for Agriculture, Fisheries, and Rural Development in the Republic of Croatia. This proposed class contains additional attributes to comply with the legal provisions related to the advantages of competitors, and the defined relation to the feature class HR_ALDP_parcel. According to these rules of 
preference, the cattle breeder is the first in the priority order, then the previous lessee of the cadastral parcel for which they are applying, then the young farmer, etc. Accordingly, the enumeration for this type of attribute value is proposed.

An overview of the application schema extension is shown in Figure 5. The model essentially tried to cover legal regulations of state-owned agricultural land management in Croatia. Certain provisions of the law were assessed as overregulated. For example, the provision that "an area exceeding 100 ha (for production-technological units) cannot be put up for disposition" can very easily be changed to, for example, 50 ha or 150 ha in future amendments to the law. The same goes for P1 or P2 soil quality. For this reason, this part is not envisaged as a limitation of the model, which in fact does not mean that they (the criteria) cannot be applied in practice. Therefore, we believe that this proposal of the LADM extension is in line with the rules of the agricultural profession, and most importantly, long-term character, while reducing its dependence on regulatory changes, which are common and frequent in the Republic of Croatia.

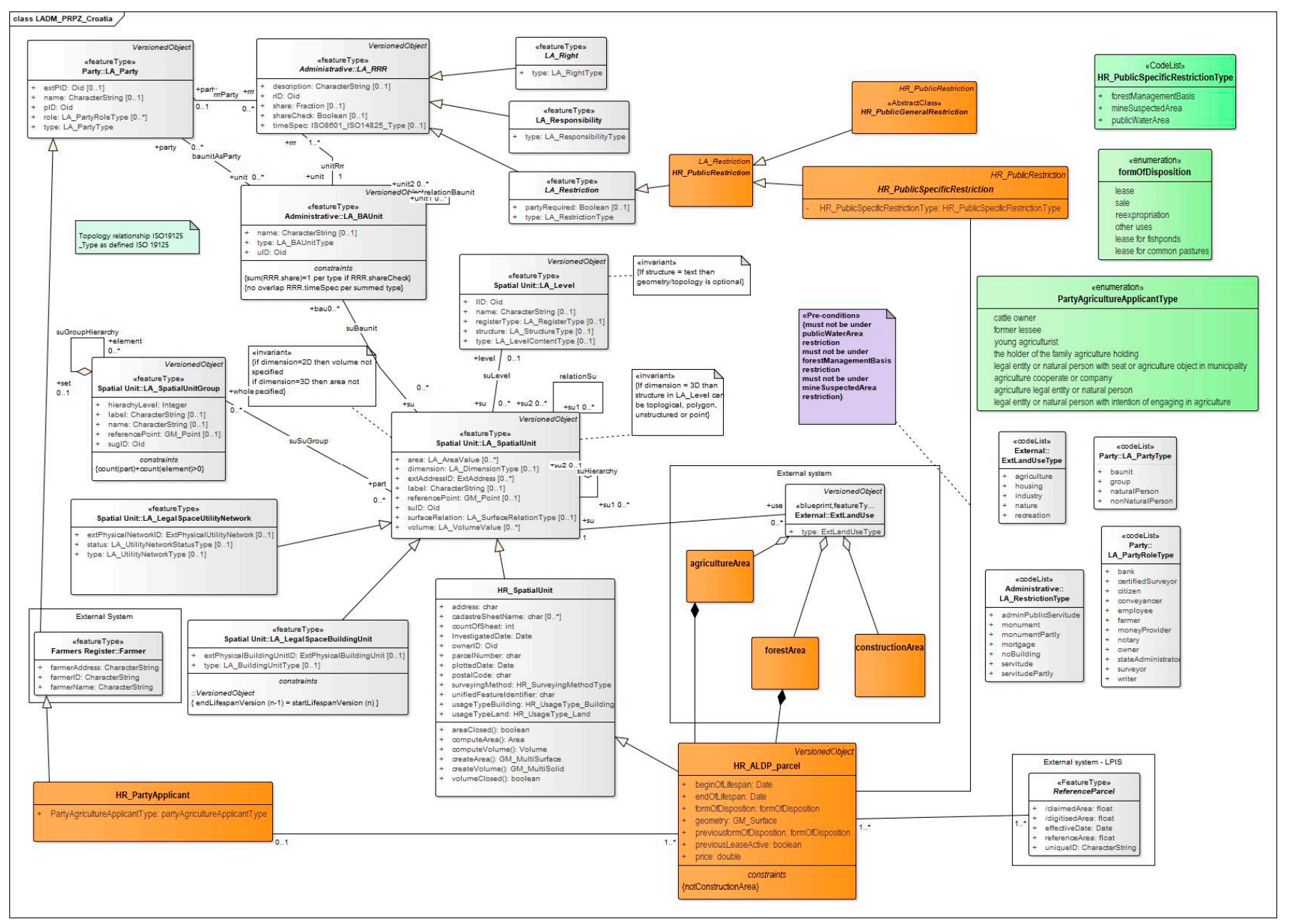

Figure 5. State-owned Agricultural Land Management extension application schema with relations to other classes (the orange and green background color presents newly added elements).

\section{Discussion and Future Improvements}

For the efficient management of agricultural land owned by the Republic of Croatia, it is necessary to connect the existing registers. The legislator should harmonize with state-of-play technological developments when adopting new regulations. For many years, the industry has been ready to harmonize and deliver spatial data and products in accordance with the INSPIRE directive and ISO and Open Geospatial Consortium (OGC) 
standards, which means spatial data services. The public sector and the relevant data institutions need to work together and coordinate to benefit from existing technology, and ultimately to speed up the process and reduce costs. The implementation of the LADM and the connection of registers, i.e., increasing the degree of interoperability in practice for secondary processes in the management of agricultural land, brings progress and reduces the possibility of errors. For example, when announcing and implementing tenders, there are often situations in which the documentation that the tenderer encloses with the application is mutually inconsistent. For example, technical data concerning areas for which subventions are given often deviate from data for the same land that are kept with other agencies, e.g., for data on cadastral parcels belonging to organic production. Here, we should make a distinction between the difference in an area from LPIS (for an agriculture reference parcel) and a cadastral parcel.

The payment of agricultural subventions for cultivated land was defined within the framework of the EU Common Agricultural Policy (CAP), which determined different characteristics of land from those registered in the cadastre. Realization of rights for subventions is possible only for cultivated land, while in the cadastre, the parcels are spatial objects of rights. The extension of the actual rights to the land and the cultivation of the land most often coincide, but deviations are not rare. There are examples in which the owner of a cadastral parcel does not cultivate it in its entirety because, for example, one part of it is barren land or is used in some other way. Some cadastral parcels are not processed by the owner but by the lessee, and the right to the subvention is exercised by the farmer, not the owner. This created the need to manage new land features, i.e., agricultural parcels that are not necessarily identical to cadastral parcels [12]. In this context, Land Parcel Identification Systems (LPIS) emerged in order to spatially represent the activities of farmers on their land. This is an identification system for agricultural parcels. In context of overlapping of LADM and LPIS, there were similar studies where authors developed LADM-based profile for farmland rights system in China [31]. Nevertheless, that research does not cover the specifics of state-owned agricultural land disposition as is common in Europe. Another research studies LADM-based profile for natural resources management in China [32]. The result of this research is converted property right structure into a domain model. Although the focus of this research is not specifically state-owned agricultural land, in one part it considers state-owned agricultural land as an object of right. Besides those studies, one research is particularly important to highlight. Because of the mutual dependencies between LPIS and land administration systems, a collaboration data model between land administration systems and agricultural land parcel identification systems was proposed in previous research [33]. The collaboration model proposed in this study concentrates on the cadastral parcel, which is represented in the model by LA_Parcel as a specialization of the super class LA_SpatialUnit. With the spatial classes of the collaboration model, the primary aim of the aforementioned research was to use cadastral parcels as the spatial basis for the identification of the reference parcel for the agricultural (CAP) application.

A similar principle was applied in the research presented in this paper. In a stateowned agricultural land disposition, we start from the cadastral parcel, because it is uncultivated in its initial state. Therefore, the entire cadastral parcel is the subject of disposition, and we cannot take only the cultivated part of the cadastral parcel, for example, to be identified as the reference agricultural parcel as in LPIS for the purpose of agriculture subventions. This is why the extension of the LADM proposes the new feature class HR_ALDP_parcel as a specialization of HR_SpatialUnit instead of the specialization of the external LPIS reference parcel. This means that LPIS cannot be directly used for stateowned agricultural land disposition but should be connected as an external system in the process. After the disposition is realized, the LPIS, integrated with the proposed LADM extension, could be used for wider purposes, i.e., agricultural land management in general, because then the parcels have become agricultural parcels. In this context, the 
model proposed in this paper presents an intermediate step between the LADM and LPIS regarding state-owned agricultural land management.

The process shown in the activity diagram (Figure 2) indicates existing issues in defined way of data exchange. The datasets used in this procedure are mainly spatial datasets, but the prescribed method of data exchange implies alphanumeric data.

The majority of spatial datasets from external registers used in the first phase of the disposition process indeed exist in digital vector format in GIS systems of the various institutions (Croatian Waters WebGIS [34], Croatian Forests WebGIS [35], Croatian Mine Action Center WebGIS [36]). Croatian Forests, Croatian Waters, and the Croatian Mine Action Center are all subjects of the National Spatial Data Infrastructure, and they maintain their spatial datasets in their own GIS systems. Certain datasets are published as a service in the Croatian NSDI Geoportal [37]. Although at the moment of accessing the NSDI Geoportal, not all the datasets required for the disposition process were published as a web service, the technological and technical preconditions within these institutions were clearly met; however, the data exchange was technologically degraded due to the regulated data exchange method.

This fact is an obstacle that could cause errors and oversights in the design of the Program. Using this data exchange method, numerous cadastral parcels that could be put into the function of agricultural production will be excluded from the Program, and certain cadastral parcels that cannot be disposed, will be included in the Program, which unjustifiably consumes existing resources. This will primarily have effects in terms of the inefficient disposal of agricultural land, inadequately used agricultural potential, and time lost preparing procedures that are not possible by the public administration. If access to cadastre and land registry data was provided through, for example, the WFS service, and the spatial data infrastructure was fully established (which implies the inclusion of all spatial data themes in this analysis and the evaluation of land potential), the analysis and data collection process would be more efficient and accurate. The procedure defined by the Law on Agricultural Land [25] and the bylaw [27] is not in line with the state-of-play of technological developments related to spatial information management, nor with the INSPIRE Directive and the Law on NSDI [38].

The model extension proposed in this research addresses the key issues in agricultural land management. With respect to upper elaborated issues, it considers utilization of existing land administration system characteristics, utilization of already available services within Croatian NSDI, service-oriented data exchange methods, and most importantly, it considers relations to external registers. If implemented this way, it would enable the disposition process to be more efficient, eliminate mistakes which could be made with current data exchange methods, and accelerate the process, which is very sluggish in current practice. The proposed model extension reduces data redundancy since it uses the existing LADM classes as much as possible. With the usage of the external classes to link the model with external registries, e.g., LandUse as an external register, implementation of this model extension would eliminate the possibility of human error when identifying the land use status of numerous cadastral parcels. This model preserves the human resource capacity in land administration system because it eliminates the need for manual processing of the data on cadastral parcels by various institutions (the department in charge for urbanism, Croatian Forests, Croatian Waters, etc.).

It would contribute to the overall LAS functionality in Croatia. The implementation of the model would facilitate the design of Programs of Disposition of State-Owned Agricultural Land by the local self-government units, and consequently increase the degree of successful realization of agricultural land disposition as the major goal. The disposition process would be accelerated since the data exchange would be dynamic and without time ranges to acquire needed datasets, and would be more efficient, realistic, and applicable since the data used to design the Program of Disposition of State-Owned Agricultural Land would be up to date. In the current Program design process, the Programs could be obsolete on the day they are defined because the datasets used are static and the status of 
the cadastral parcels could be changed, with respect to the fact that Programs could be in phase one (the preparation and development of the Program) for several months.

As can be seen for tasks such as land valuation and categorization, it is necessary to use datasets of different topics, regardless of the purpose of the land that is the subject of the evaluation; thus, we can conclude that the principle of multi-criteria decision analysis (MCDA) is applicable to other disciplines for land potential evaluation [26]. Regarding this fact, the full production of spatial data infrastructure and the usage of data services for this kind of task, instead of conservative static data exchange methods, is a necessity.

\section{Conclusions}

Previously to this research, several LADM Country Profile proposals were already introduced. The majority of the LADM core schema passed the abstract test suite when tested against the Croatian Land Administration System (LAS), showing a high level of compatibility.

Therefore, the LADM can be applied in Croatian LAS. For the needs of cadastral parcels of agricultural land disposition, smaller profile extensions have been proposed.

In this research, we proposed an extension to the Croatian LADM profile, to fit the needs of state-owned agricultural land management. An activity diagram that follows the process defined by the regulations regarding state-owned agricultural land was created. According to the activities in the process and the objective, which was the successful disposition and monitoring of state-owned agricultural land, the extension was modeled. In the proposed extension, only two new classes were added (HR_ALDP_parcel and HR_PartyApplicant), while the majority of classes and attributes required in agricultural land management were recognized in the schema matching process in the existing Croatian LADM profile.

When modeling the proposed profile extension, interoperability was taken into account, as well as the applicability of the model, not only to agricultural land, but also to general land potential evaluation processes for decision-making. This was initially guided by the need for multi-criteria decision analysis for the Program of Disposition of StateOwned Agricultural Land. Therefore, in overview of the application schema that displays the entire extension model, which is proposed, there can be seen that certain elements of the model were resolved with relation to external systems. This is important for other processes, such as mass property evaluation, different risk or potential analyses, investment analyses, crisis management, location analyses, and decision support in general.

Therefore, the proposed model envisages as many connections to external systems as possible. It defines relations between classes, instead of unambiguously adding attributes to a specific class. The latter would create redundant unsynchronized data.

There is room for improvement in regulations. In addition, practice, industry, and even part of the public sector, as seen in previous research, demonstrate readiness to apply digital land management technologies and adopt a formal land management model.

Author Contributions: J.L. worked on all sections of the manuscript, created UML models, analyzed the data, and created original draft manuscript; M.R. conceived and designed the structure of the paper, and suggested the methodology and particularly the activity diagram, and was active in review and editing of the manuscript; H.T. contributed to all sections of the manuscript, participated in data analysis, and contributed to literature review; S.M.I. was performing supervision of the work, and contributed to overall guidance of the paper structure design, and contributed in positioning of this particular research into the wider research context regarding land management. All authors have read and agreed to the published version of the manuscript.

Funding: This research received no external funding.

Data Availability Statement: Publicly available datasets were analyzed in this study. This data can be found here: https:/ / pozega.hr/ (accessed on 5 February 2021). 
Acknowledgments: The manuscript is developed on top of the state-owned agricultural land disposition process in use case of City of Požega, Croatia. The authors would like to express gratitude to the City of Požega which published the input data on official website.

Conflicts of Interest: The authors declare no conflict of interest.

\section{References}

1. Roić, M. Implementation of the Land Governance Assessment Framework in the Republic of Croatia; World Bank Other Operational Studies 28509; The World Bank: Washington, DC, USA, 2016.

2. Ministry of Agriculture. Rural Development Programme of the Republic of Croatia for the Period 2014-2020; Ministry of Agriculture: Croatia. Available online: http:/ /www.fao.org/family-farming/detail/en/c/418102/ (accessed on 20 November 2020).

3. Law on Agricultural Land. Off. Gazet. 1991,34. Available online: https://narodne-novine.nn.hr/clanci/sluzbeni/full/1991_07_ 34_945.html (accessed on 11 November 2020).

4. Kontrec, D. Pravni status i raspolaganje poljoprivrednim zemljištem u Republici Hrvatskoj—povijesni prikaz, de lege lata, de lege ferenda. Rad. Zavoda za Znan. rad HAZU Varaždin 2014, 631, 69-95.

5. Svržnjak, K.; Franić, R. Developing agrarian structure through the disposal of state-owned agricultural land in Croatia. Agroecon. Croat. 2014, 4, 50-57.

6. Odak, I.; Tomić, H.; Matelić Ivić, S. Vrednovanje fragmentacije poljoprivrednog zemljišta. Geod. List 2017, 3, $215-232$.

7. Mičević, B. Razvoj Sustava za Upravljanje Poljoprivrednim Zemljištem u Okviru Poljoprivredne Politike Republike Hrvatske. Ph.D. Thesis, University in Zagreb, Zagreb, Croatia, 2016.

8. International Organization for Standardization. Geographic information-Land Administration Domain Model (LADM). Land Use Policy 2012, 19152, 1-118.

9. INSPIRE Thematic Working Group for Cadastral Parcels Infrastructure for Spatial Information in Europe D2.8.I.6 Data Specification on-Cadastral Parcels. 2014. Available online: https://inspire.ec.europa.eu/documents/Data_Specifications/INSPIRE_ DataSpecification_CP_v3.0.1.pdf (accessed on 20 November 2020).

10. INSPIRE Thematic Working Group Land Cover Infrastructure for Spatial Information in Europe D2.8.II.2 Data Specification on Land Cover-Technical Guidelines. 2013. Available online: https: / www.google.com $/$ url? sa =t\&rct=j\&q=\&esrc=s\&source=web\& $\mathrm{cd}=\& v e d=2$ ahUKEwja1reawvzuAhXRZt4KHQ8WDzgQFjAAegQIARAD\&url=https\%3A\%2F\%2Finspire.ec.europa.eu\%2Fid\% 2Fdocument\%2Ftg\%2Flc\&usg=AOvVaw165UN31SUQ4151mcrVpWuD (accessed on 20 November 2020).

11. Kalogianni, E.; Kalantari, M.; Dimopoulou, E.; Oosterom, P.V. LADM country profiles development: Aspects to be reflected and considered. In Proceedings of the 8th Land Administration Domain Model Workshop (LADM 2019), Kuala Lumpur, Malaysia, 1-3 October 2019; pp. 287-302.

12. Roić, M. Upravljanje Zemljišnim Informacijama_Katastar; Geodetski Fakultet Zagreb: Zagreb, Croatia, 2012; ISBN 978-953-6082-16-2.

13. Lemmen, C.; van Oosterom, P.; Kara, A.; Kalogianni, E.; Shnaidman, A.; Indrajit, A.; Alattas, A. The scope of LADM revision is shaping-up. In Proceedings of the 8th Land Administration Domain Model Workshop (LADM 2019), Kuala Lumpur, Malaysia, 1-3 October 2019; pp. 1-36.

14. Lemmen, C.; van Oosterom, P.; Bennett, R. The Land Administration Domain Model. Land Use Policy 2015, 49, 535-545. [CrossRef]

15. Lemmen, C.; van Oosterom, P.; Uitermark, H.; de Zeeuw, K. Land Administration Domain Model is an ISO Standard now. In Proceedings of the Annual World Bank Conference on Land and Poverty, Washington, DC, USA, 8-11 April 2013.

16. Van Oosterom, P.; Lemmen, C. The Land Administration Domain Model (LADM): Motivation, standardisation, application and further development. Land Use Policy 2015, 49, 527-534. [CrossRef]

17. Vučić, N.; Mađer, M.; Roić, M.; Vranić, S. TOWARDS A CROATIAN 3D CADASTRE BASED on the LADM. ISPRS Ann. Photogramm. Remote Sens. Spat. Inf. Sci. 2017, 4, 399-409. [CrossRef]

18. Vučić, N.; Roić, M.; Kapović, Z. Examination of Compatibility Between the Croatian Land Administration System and LADM. Dev. Multidimens. Spat. Data Model. 2013, 155-171. [CrossRef]

19. Vučić, N.; Markovinović, D.; Mičević, B. LADM in the Republic of Croatia-Making and testing country profile. In Proceedings of the 5th FIG International Land Administration Domain Model Workshop, Kuala Lumpur, Malaysia, 24-25 September 2013.

20. Tomić, H.; Mastelić Ivić, S.; Roić, M.; Jurakić, G. Are Croatian Official Registers complying with the LADM Fiscal/Valuation Extension? In Proceedings of the 7th Land Administration Domain Model Workshop (LADM2018), Zagreb, Croatia, 12-13 April 2018.

21. Law on Communal Economy. Off. Gazet. 2018,68. Available online: https://narodne-novine.nn.hr/clanci/sluzbeni/2018_07_68 1393.html (accessed on 15 November 2020).

22. Rahm, E.; Bernstein, P.A. A survey of approaches to automatic schema matching. VLDB J. 2001, 10, 334-350. [CrossRef]

23. Wang, G. Schema Mapping for Data Transformation and Integration. Ph.D. Thesis, University of California, Berkeley, CA, USA, 2006.

24. Mutambo, L.S. The Unified Modelling Language (UML) in Cadastral System Development. Master's Thesis, Innovation and Technology Commission, Hongkong, China, 2003.

25. Law on Agricultural Land. Off. Gazet. 2018, 20. Available online: https://narodne-novine.nn.hr/clanci/sluzbeni/2018_03_20_4 02.html (accessed on 15 November 2020). 
26. Lisjak, J.; Roić, M.; Tomić, H. Višekriterijske analize u interdisciplinarnoj primjeni-primjer raspolaganja poljoprivrednim zemljištem. In Proceedings of the 12th Symphosium of Chartered Geodetic Engineers; Croatian Chamber of Chartered Geodetic Engineers, Opatija, Croatia, 18-20 October 2019; pp. 58-66.

27. Rulebook on Documentation Needed for Making Program of Disposition of State-Owned Agricultural Land. Off. Gazet. 2018, 27. Available online: https:/ / narodne-novine.nn.hr/clanci/sluzbeni/2018_03_27_555.html (accessed on 15 November 2020).

28. Roić, M.; Tomić, H.; Mađer, M. Ocjena i unapređenje okružja uređenja zemljišta u Hrvatskoj. In Proceedings of the VI Croatian Congress on Cadastrev \& LADM2018, Zagreb, Croatia, 11-14 April 2018; pp. 133-141.

29. Mađer, M.; Matijević, H.; Roić, M. Analysis of possibilities for linking land registers and other official registers in the Republic of Croatia based on LADM. Land Use Policy 2015, 49, 606-616. [CrossRef]

30. Paasch, J.M.; van Oosterom, P.; Lemmen, C.; Paulsson, J. Further modelling of LADM's rights, restrictions and responsibilities (RRRs). Land Use Policy 2015, 49, 680-689. [CrossRef]

31. Zhuo, Y.; Xu, Z.; Li, G.; Liao, R.; Lemmen, C.; Wu, C.; Wu, Y. LADM-based profile for farmland Tripartite Entitlement System in China. Land Use Policy 2020. [CrossRef]

32. Xu, Z.; Zhuo, Y.; Liao, R.; Wu, C.; Wu, Y.; Li, G. LADM-Based Model for Natural Resource Administration in China. ISPRS Int. J. Geo-Inf. 2019, 8, 456. [CrossRef]

33. Inan, H.I.; Sagris, V.; Devos, W.; Milenov, P.; van Oosterom, P.; Zevenbergen, J. Data model for the collaboration between land administration systems and agricultural land parcel identification systems. J. Environ. Manag. 2010, 91, 2440-2454. [CrossRef] [PubMed]

34. Croatian Waters. Geoportal. Available online: https://www.voda.hr/hr/geoportal (accessed on 22 November 2020).

35. Croatian Forests. WebGIS. Available online: http://javni-podaci.hrsume.hr/ (accessed on 22 November 2020).

36. Mine Suspected Areas. WebGIS. Available online: https://misportal.hcr.hr/HCRweb/faces/intro/introduction.jspx (accessed on 22 November 2020).

37. Croatian NSDI Geoportal. Available online: https:/ / geoportal.nipp.hr/ (accessed on 22 November 2020).

38. Law on National Spatial Data Infrastructure. Off. Gazet. 2013, 56. Available online: https://narodne-novine.nn.hr/clanci/ sluzbeni/2013_05_56_1135.html (accessed on 22 November 2020). 